\title{
COMMENTARY
}

\section{Legal education for social work students: Toward an interdisciplinary framework of teaching and practice}

\author{
Vered Ben David \\ School of Social Work, Zefat Academic College, Israel
}

\section{Check for updates}

Correspondence to: Vered Ben David, School of Social Work, Zefat Academic College, Israel;

E-mail: vered_bd@hotmail.com

Received: February 25, 2021;

Accepted: March 22, 2021;

Published: April 6, 2021

Citation: Ben-David V. Legal education for social work students: Toward an interdisciplinary framework of teaching and practice. Soc Work Soc Welf, 2021, 3(1): 111-120.

https://doi.org/10.25082/SWSW.2021.01.004

Copyright: () 2021 Vered Ben David. This is an open access article distributed under the terms of the Creative Commons Attribution License, which permits unrestricted use, distribution, and reproduction in any medium, provided the original author and source are credited.

\section{(i) (5)}

\begin{abstract}
Since social work practice interfaces with the law in various ways, there is a need to integrate legal studies into social work education. Currently, social work curricula leave little room for basic legal education and, furthermore, there appears to be a general negative reaction to the law among social workers. This paper presents a comprehensive analysis of the importance of law to social work, and discusses aspects of the law that are particularly valuable to social work education and practice. We contend that it is vital to provide social work students with basic legal education in order to promote efficient social work practice and collaboration between the law and social work. We analyze inter-connections between social work and legal disciplines and discuss the challenges and benefits derived from combining the two disciplines. Key areas of legal education that should be addressed in order to educate future effective social work practitioners are also discussed. The discussion is based on our experience in providing legal education to social work students, our belief in the importance of law to social work, and our experience in the practice of both legal and social work.
\end{abstract}

Keywords: legal education, social work students, interdisciplinary framework

\section{Introduction}

Social work practice interfaces with the law in various ways. The law influences social work explicitly and implicitly [1]. For example, the law determines the social worker's authority to intervene in the lives of individuals, families and communities, the types of interventions that can be taken and the conditions required for such interventions. The law also supports social work values such as the right to confidentiality, equal opportunity, social justice, freedom from discrimination and oppression and the need for balance between intervention and individual freedom [1].

There is a general consensus that the law is very relevant to social work practice and there is a need to integrate legal studies into social work education [2,3]. Knowledge of the legal system and the development of skills to work within the system are considered powerful tools for effective social work practice [1]. Scholars and social work educators have called for "increased attention by the social work profession to legal scholarship and the development of legal knowledge related to social work practice" [4]. A well-informed social worker means a competent social worker. Social work students thus require knowledge of the law in order to be better practitioners [3]. Creative thinking is also necessary for effective problem-solving (Luca Fazzi, 2016) and this includes an understanding of the interdisciplinary dimensions of social work practice in order to deal with complex problems [5].

Legal education, however, is still the exception rather than the norm in social work education. Studies reveal that social work curricula leave little room for basic legal education and research, financial and time constraints were found to be prohibitive factors[6,7] while another study has shown that social workers do not possess sufficient knowledge of relevant laws [4]. There also appears to be a general negative reaction to the law among social workers that is driven by emotions rather than objective assessments [8], for they view the law as oppositional to social work values[2,8]. Not surprisingly, it was found that social workers tend to refrain from applying legal interventions in a case, preferring primarily therapeutic/treatment interventions in cases of elder abuse [9]. Studies have revealed that social workers feel disdain for and a certain fear of the law and the legal system. This was attributed to insufficient knowledge of the law as well as fear of a conflict of interest between the values of social work and those of the law $[3,10]$. 
In this paper, we seek to expand the existing literature on legal education for social work students. We present a comprehensive analysis of the importance of law to social work, and discuss aspects of the law that we consider valuable to social work practice. We analyze interconnections between social work and legal disciplines, as well as the challenges and benefits derived from combining the two disciplines. The discussion will be general in nature, so that it can be generalized and customized to social work education in various places. While we refer to examples to demonstrate our arguments, we do not discuss specific laws but examine more broadly the relevance of law to social work. We present key areas of legal education that we believe should be addressed in order to educate future effective social work practitioners. The discussion is based on our experience in providing legal education to social work students, our belief in the importance of law to social work, and our experience in the practice of both legal work and social work. We contend that it is vital to provide social work students with basic legal education in order to promote efficient social work practice and collaboration between the law and social work.

In the first part of the paper, we discuss basic differences between both disciplines that may explain the gap between the importance of law to social work education and the disconnection that exists between the two disciplines. In the second part, we describe our experience providing legal courses to social work students. In the third part, which comprises the bulk of the paper, we discuss how social work practice is shaped by the law and points of interaction between the law and social work. We analyze different aspects of the profession that are impacted by the law and discuss how the law can serve to promote social work values and practical work. The paper concludes with a perspective into future collaboration between social work and legal education.

\section{Differences between Legal and Social Work Domains}

An explanation for the disconnection between the law and social work is rooted, in our opinion, in the difference between the two disciplines. We believe that acknowledging the differences between law and social work is the first fundamental step toward constructing an interdisciplinary collaboration.

Historically, social work was founded as a helping profession. The goal of social work is to help individuals, families and community, alleviate suffering, and promote wellbeing and empowerment. Another ethical value is also the pursuit of social justice. Social workers strive to ensure access to information, services, and resources; equality of opportunity; and meaningful participation in decision making for all people. The nature of the profession stands in sharp contrast to the basis of law. Laws were instituted in order to regulate the social world and social interaction. Laws are a means of organizing the lives of members of a given society [11]. A key role of laws is the creation of social norms that guide the behavior and actions of members of a society. The professional expertise of lawyers includes identification, interpretation and application of legal rules and concepts [12]. It is limited to legal issues and the promotion of social justice is not an explicit professional responsibility. It is clear that alleviating suffering and ensuring social justice is quite different from regulating social behavior and interpreting the law. Not surprisingly, the type of services provided by each profession is also different. Social workers provide a broad array of services ranging from individual casework, group work, community organization to social reform. Lawyers provide legal counsel, representation, and advocacy to individual clients [12].

Social work is process-oriented while law is outcome-oriented. Social work interventions are usually based on processes of change and the creation of a relationship of trust between the client and the social worker is a key factor in achieving a desired change. The client and the client's needs stand at the center of the process. A guiding principle in social work is that every intervention should be tailored to the specific needs of the client. There is understanding that change may take time and is dependent on the interplay between multiple factors at the individual, social, communal and cultural levels. Social workers employ a system theory approach which helps them formulate the problem and the solution from a broad social perspective, taking into account systemic and structural factors.

In contrast, the aim of the law is to define specific behaviors and relations between the individual, the state and institutions. Lawyers usually formulate the client's problem within a narrow specific law. The system in which a problem occurs is considered irrelevant and there is no tolerance of any violation of the law. Consideration of various legal remedies or legal responses is limited by the law. Furthermore, conflict resolutions via legal adversarial proceedings arrive at conclusions such as guilty or not, negligent or not, legally responsibility or not. Emotional processes which individuals may go through during a legal litigation are irrelevant to the legal process as are factors such as poverty, discrimination, educational and 
employment opportunities (unless otherwise stated by the law).

Another major difference is the language used in each domain. Since the law aims at regulating behavior it has to be inclusive and cover as many cases as possible. Legal norms are, therefore, articulated in a broad, abstract manner. The language is general and formal and may often appear complicated and incomprehensible to the lay man. The language of the law cannot, by definition, be personal or specific. The language of social work is more intuitively understandable: it is emotional and personal in nature. Social workers use terms such as empathy, sensitivity, empowerment, relationship, process, feelings, reflection, in order to describe an intervention plan or case (e.g., [13]).

Violation of the law leads to coercive action by the state, whereas social work is fundamentally based on a consensual, trust relationship, with the client at the center. These differences need to be taken into account when designing a legal program for social work students. It is important to acknowledge that differences in the professional education, training, expertise, practice, and professional ethics of lawyers and social workers [12] may prevent social workers from applying legal solutions to a case or, even more importantly, from using the law as an intervention tool where relevant. Building bridges between legal and social work education requires a wellthought curriculum that integrates legal materials into social work issues in clear, understandable ways. When teaching law to social work students there should be, in our opinion, a continuous discussion of how knowledge of the law, in general or with regard to a particular issue, can promote the goals of social work and how it is aligned with social work values or stands in opposition to it. We have purposefully elaborated on the differences between the two professions in order to highlight possible points of collision and promote a deeper understanding of the legal world.

Two points of common interest are noteworthy: both the legal and social worlds deal with social interaction at the micro and macro levels - either between individuals or between individuals and government, agencies or other legal entities. They both explain human complexity even if from different angles. Legal knowledge, intertwined with social work knowledge, can provide a more comprehensive picture of a client's condition and promote a holistic solution. The second point is that despite the differences outlined above, the nexus between both disciplines relates to a shared acknowledgment of the importance of human rights (we elaborate on this point in the third section). Students need to understand principles of law but, at the same time, the guiding question should be how knowledge of the law empowers social work practice and promotes more competent social workers.

\section{Legal Education for Social Work Students at Zefat Academic College}

In order to narrow the gap between theory and practice and acknowledge the importance of the law to social work practice, the Social Work School of Zefat Academic College decided to launch several years ago a series of courses entitled: "The Organizational and Legal Framework of the Social Work Profession in Israel", "the Israeli Legal System", and "Parental Capacity in the Child Protection Context". The first course focuses on social work and the law and discusses the interplay between the two bodies of knowledge, with specific attention to issues relevant to social work practice. The course is mandatory and students are required to take it for the completion of their BA degree. The second course is an introductory course on the law and legal principles in a democracy, with an analysis of the social and political context in which the law operates. The last course examines social work and legal aspects of parental capacity in child maltreatment cases, with critical analysis of the decision-making process in child protection. The two latter courses are elective for first and third year students. The courses are given by a lecturer who is both a social worker and a lawyer (Ph.D.), with extensive practical, academic and research experience in both disciplines. The lectures include presentations and discussions of relevant legislation, court rulings and social work research. The first course ("The Organizational and Legal Framework of the Social Work Profession in Israel") emphasizes the importance of legal education for social work students. It exposes students to the legal aspects of issues such as domestic violence, child maltreatment, juvenile delinquency, mental illness and rights advocacy. Every topic is presented comprehensively from social work and legal standpoints in order to enable students to integrate the new legal material into the context of social problems under discussion. The ultimate goal is to expand the students' skills and arsenal of intervention tools by including possible legal solutions. Expanding the knowledge base of students with regard to the legal system also contributes to reducing feelings of fear and anxiety that can arise during field work when social workers encounter situations that demand a legal 
response or when legal considerations must be taken into account at a particular juncture in a case. This could be, for instance, when deciding whether or not to remove a child from his biological home to alternative care or whether to advise a client to file for a restraining order against a violent partner.

Three learning goals were defined: to inform students about specific legal issues they are likely to encounter in their daily work with a child welfare population: to familiarize students with legal terminology such as rights, due process, courtroom, legal officers, court reports, discretion, depositions, termination of parental rights, parental capacity, risk and so on; to teach students how to read and comprehend legislation and become acquainted with the rules of the executive branch of government to which they will probably be affiliated following graduation.

We now briefly describe the personal experience of the first author when teaching this course in the hope it will give readers a first-hand impression of the challenges and opportunities involved in trying to provide legal education to social work students. As a facilitator on this course, I (the first author) have observed a dual reaction among students, especially at the beginning of the course: on the one hand they are highly interested in learning what the law says about topics they have studied, topics relevant to their field work and general social problems (such as when a woman is murdered by her husband, a child is abused by his parents, or an elderly person is treated badly or neglected). Students are eager to know what the law says in these cases, how violation of the law can lead to a tragic end, and how enforcement of the law can prevent such cases. The general perception of the law by students at this initial point is as a powerful deterrent tool that is supposed to take care of such situations and provide the appropriate arrangements for dealing with them. Even if the student does not understand the specific law that is relevant to a case, the law is viewed as providing a sanctuary against untoward outcomes.

On the other hand, the law is perceived by students as something that is outside and strange to the social work realm, as something formal, harsh and lacking empathy; something more procedural and less substantive, involving numerous technicalities and formal procedures, which require special training and education to be understood. They also express concern about their ability to enter the world of law. This duality diminishes as the course progresses and, in the final stages, students report a feeling of empowerment and greater understanding of the law and legal solutions.

I have observed, during the course, that application of studied materials is almost immediate: students are able to connect what they learn in class to their practical work with clients. They are also able to argue whether the connection of specific law with a specific case is appropriate. Overall, the experience of both the teacher and students is positive. The main challenge, however, is to impart critical analytical legal skills to the students. They often find it difficult to understand how the application of the law promotes or hinders the promotion of social work and legal values such as fairness and justice or wellbeing. Practice and discussion of the law with students is necessary in order to build the kind of skills students need apply legal rules and use the law in their work. This is a continuous process that does not end with graduation. It will be sharpened and acquire specific form in the context of the student's future employment. We now explore the various ways in which the law interfaces with social work.

\section{The Importance of Law to Social Work Practice}

In the following segments we examine the importance of law to social work practice from various perspectives. We present five arguments describing why, in our view, legal education for social work students is necessary in order to train competent social workers. We describe how different aspects of social work practice intersect and conflate with the law and why knowledge of the law is important to the professional work of social workers. We contend that legal education is vital because: there are laws specific to social work and there are laws which are not specific to social work but address issues relevant to social work; social workers need to know administrative law in order to lawfully execute the authority granted by law; social workers deal with diverse professions and institutions and need to be familiar with the legal system to manage cases and coordinate services; the law is a powerful tool for social change which is part of the social worker's ethical duty as an agent of change; legal knowledge of basic international law and human rights is required, particularly in current times, in order to deal with diverse minority groups. All five arguments can be seen as representing a continuum ranging from specificity to generality and reflecting different levels of social work practice. The legal education of social workers, as described in the current paper, follows an ecological model (Bronfenbrenner, 1979, 1986). We demonstrate that legal knowledge is required for all levels of social work practice, from micro to macro. 


\subsection{The law as a significant regulator of the social work profession}

The law regulates many aspects of social work practice and is therefore a key to the lawful execution of social workers' authority. In Israel, the social work profession is governed by 194 laws [14]. This legislation refers to various domains of social work but covers primarily the following areas: children and families at risk, physical and mental disabilities, criminal justice of minors and adults, ethics, elderly people, social security, community organization and localities, and psychotherapy.

Generally, the law determines the situations, causes and circumstances that demand social worker intervention, social services or eligibility for services. Knowledge of the law is necessary in order for social workers to operate within the boundaries of the law and appropriately execute the power granted to them by the law to intervene in the lives of individuals, families or communities and deliver services to eligible recipients. For example, the interaction of the law with the child welfare system is designed to cater to children and youth in need of protection [15].

In Israel, the law entitled: Adolescents - Treatment and Supervision Act, 1980, deals with minors at risk and determines the causes for legally declaring a minor as a "minor in need." This declaration is necessary when there is a risk to the child's mental and/or physical health. The courts base their decisions on mandatory social workers' reports and professional assessments of the family. If a child is in need of protection and a family does not cooperate with the social worker's intervention plan, the social worker files a request to declare the child a "minor in need." In this case, the law elaborates on the types of intervention that can be taken to secure the child's safety and healthy development and the social worker makes recommendations to the courts in this regard. For example, the social worker can recommend removing the child from his/her biological home to an out-of-home placement, or place the child under the supervision of the social worker, with parental authority transferred to the social worker. A social worker who is qualified as a child and adolescent officer is responsible for applying the law and taking action to protect minors at risk. It is clear that knowledge of the law in such cases is mandatory for the social worker.

In some cases, lack of knowledge of the law can have severe consequences for the social worker. For example, under Israeli law, it is obligatory to report an incident of child maltreatment to the police or designated social worker. Violation of the law can result in a fine and/or a sentence of up to six months in prison. Knowledge of the law is therefore essential in order to act in a professional manner and abide by the law.

In addition to legislation that directly deals with the social worker's power to take action, there are laws which do not refer specifically to social workers but address issues relevant to social work practice such as laws on domestic violence, the disabled, social security and so forth. Basic knowledge of these laws and the arrangements they provide is necessary in order to ensure the provision of professional services and treatment plans. The social worker should be familiar with the legal context of particular cases in order be able to guide their clients and advance their best interests.

\subsection{The importance of legal principles to the professional judge- ment of social workers and their execution of the law}

Knowledge of fundamental legal principles is needed in order for a social worker to act lawfully when intervening in a case. As noted in the previous section, the law determines the authority of the social worker to intervene and take action in different situations. Usually the law grants wide discretion to social workers in their decision making process. When a social worker executes an authority granted to him by the law he acts as a governmental official. The social worker is considered in these cases a "public authority" and has to abide by administrative and constitutional laws. Since social workers often have to make grave decisions with harsh consequences, a legal education in the principles of administrative and constitutional law is essential in order to ensure fair decisions and protection of clients' rights. It should be noted that this aspect of the law is not specific to social workers but applies to every official who possesses an authority granted by law.

Social work students should be familiar with legal terminology and have substantive knowledge of key principles such as civil rights, human rights, equality, human dignity, antidiscrimination laws, freedom and constitutional separation of power. A major principle of jurisprudence is that every law should be interpreted in light of basic human rights and values [11]. Every execution of the law should therefore strive to implement and align with these rights and values. Rights and values can be limited, however, when there is a need to balance opposing rights and values. Social workers have discretion to make judgements but they 
need to take into account the rights of every party in a case and strike a balance between the various interests, such as the need to protect a child versus the constitutional right of parents to parenthood [16]. In addition, as public officials social workers need to apply basic public rules, make "reasonable" decisions, decisions in good faith and follow due process. As a public authority, the social worker must assume powers granted by the law in a reasonable manner, that is, act in a way that a "reasonable social worker" would act in a similar situation.

This requirement means that the actions or decisions of social workers must fall within the range of possible options of actions or decisions that are acceptable to the social work profession. In other words, a social worker's actions, behavior or intervention does not necessarily have to be exactly the same as those of other social workers in similar circumstances but should not fall beyond the boundary of reasonable options that represent the general consensus. Another principle alludes to the need to operate in good faith and avoid bias of any kind while implementing legal authority, including gender, race, ethnical or religious bias. In practice, this means following due process whenever there is a risk of violating a client's civil or human rights. It is important for the voice of the client to be heard, for the client to express his/her opinion and for this opinion to be fully considered by the social worker. For example, a social worker who makes the decision to remove a child out of his/her home and place the child in alternative care must balance the family's right to autonomy and privacy against the need to protect the child. Removal of a child from his/her home is a last recourse after considering less harsh possibilities that entail minimum violation of parental rights. Furthermore, since parents have a constitutional right to parenting, they must be allowed to express their version of events, as well as their preference and opinion regarding the child's placement. Social workers therefore need to integrate their professional knowledge with basic legal knowledge when considering removal of a child from the house, reunification of the child with the parents, the risk to the child and other issues concerning children and parents.

\subsection{Knowledge of the organizational structure of the legal system}

It is important for students of social work to acquire basic knowledge of the structure of the legal system in order to be able to navigate their way in the system. Structural knowledge refers to the structure of the law, the judiciary and the law enforcement process. This knowledge enables social workers to communicate effectively with legal representatives and ensure the best interests of the client [1].

Social workers work in various agencies and organizations and are often part of a "multidisciplinary team" that includes professionals from different disciplines, such as lawyers, legal consultants, and legal analysts [17]. Understanding other disciplines is a key to interdisciplinary collaboration [18]. For example, social workers in Israeli Welfare Departments are part of an interdisciplinary committee which decides on intervention plans for minors at risk; health social workers are part of an interdisciplinary team in medical centers which coordinates health care services for individuals and populations [19]; and social workers can be appointed by the courts as state guardians of individuals who suffer from mental illness or developmental disabilities and are unable to make decisions on their own behalf [7]. In all these cases, knowledge of the law in general (main concepts and principles) and the structure of the legal system is necessary in order to understand the legal system, the key players in the legal arena and the forms of procedures that have to be followed in a case.

Knowledge of the structure of the law includes: the nature of the adversary process; the difference between civil law and criminal law; major principles and practices of both areas of the law, such as the goal of the law, criminal/civil law procedures, legal outcome of civil law (i.e., restitution, restraining orders, mandatory injunctions) and criminal law (i.e., jail, probation, community work); law of evidence (i.e., admissibility of evidence, validity and reliability of evidence, investigation of witnesses) including witness preparation, expert testimony and report writing [1].

Other knowledge covers the authority and roles of all branches of the judiciary system including family courts, district courts, labor courts and the Supreme Court: students learn about the hierarchy between the judicial instances, the right of appeal to a court ruling, legal precedents and basic jurisprudence rules, the role of judges, the difference between legal truth and factual truth, the legal decision-making process, interpretation of the law according to constitutional values, significance of human rights and civil rights as guiding principles in interpreting the law and so forth. In regard to law enforcement, students learn about the Department of Justice which is responsible for the submission of law proposals and includes the office of the Attorney General; the role and authority of the police (arrest, enforcement and investigatory roles); enforcement of civil law by the special unit designated for this purpose in the judicial branch. 


\subsection{The law as a tool of social change}

Social work traditionally promotes social justice and human rights [20] Martnez Herrero, \& Charnley, 2019) and social workers also often strive to promote social change and assist socially marginalized groups. Legal knowledge and skills can contribute significantly to this end [8].

The law constitutes a powerful tool for promoting social change. As a proactive tool for collective action [8], the law can bring about change on a large scale and affect the lives of many people. Legislation can cover the protection of the rights and interests of individuals and groups as well as remedies in case of violations. For example, in Israel the Equal Rights for People with Disability Act, 1998 ensures that individuals with mental and physical disabilities enjoy the same rights as individuals without disability in respect of the right to human dignity, accessibility to public places, employment, public service and more. This law represents the culmination of longstanding efforts to promote justice for people with disabilities and enhance their quality of life.

The law can also be used to challenge existing power structures and processes that promote social exclusion. For example, social workers who advocate for members of the LGBT community are obliged to challenge existing laws when promoting anti-discriminatory and anti-oppressive practices [21].

When executing their ethical duty as social agents, social workers strive to protect the rights and interests of oppressed, discriminated, vulnerable and disadvantaged groups. To this end, social workers engage in social activism, community based-organization, advocacy mediation [22], conflict resolution, mediation and so forth [7] and, in so doing, they have to deal with various stakeholders such as lawmakers, policymakers, governmental officials. In order to function effectively in the legal and public spheres, social workers need to be familiar with legislation processes, key legal terminology and principles that promote the interest they represent. Equally, they need to be able to present their case in a broad human rights context, identify areas where access to services may be limited (e.g., housing, medical services, education, social security), or challenge policies that may cause unfair/harmful distribution of resources or exclusion of specific groups of people. The social worker's unique professional knowledge of individuals and families and holistic view of complex social problems are invaluable to the design of public policy.

Knowledge of the law enables social workers to be actively involved in the public discourse and to examine whether certain laws meet the basic requirements of fairness and justice. Legal knowledge is even more necessary if social workers wish to be gatekeepers of humanitarian considerations and the protection of human rights. They should possess the tools to enable them to critically examine the social realities of certain laws, meaning, the possible outcomes of public policy and bring to public awareness potential negative repercussions or unintended results.

\subsection{Knowledge of international law}

Due to globalization, immigration and migration processes, social workers are more than ever likely to come into contact today with individuals and groups of people from diverse cultural, ethnical and social backgrounds. In order to effectively deliver sensitive multicultural services, they need to possess basic knowledge of human rights and international law. They need to be able to base their work on human rights principles and contextualize individual issues within a broad human rights framework $[23,24]$.

International law reflects universal, basic principles relating to justice, fairness, amelioration of suffering, human dignity, the need to protect minorities and so forth. It provides an umbrella of rights aimed at protecting marginalized groups or individuals from vulnerable parts of the world. International law also represents agreements between nations on the need to fight social problems on a global scale and abolish abuse of children, women and human beings for trade and profit. In general, international law calls for the protection of the dignity and rights of people regardless of their citizenship status. Various laws and treaties govern social work practice with individuals and groups. Prominent examples include: the international law regarding the protected status and legal rights of refugees and asylum seekers who are forced to flee their countries due to wars, climate catastrophes, political or ethnical persecution [25, 26]; treaties between countries to stop human trafficking and prevent trade in human organs [27]; the UN Convention on the Rights of the Child; the Universal Declaration of Human Rights; extradition treaties between countries for criminal offenders; requirements to provide humanitarian and medical aid to people in need and so on. 
Education on human rights should be integrated into the social work education paradigm $[20,23,24]$. Students need to learn about the importance of human rights and the need to protect human rights especially in times of crisis. This aligns with the ethical obligation of social workers to protect the dignity and interests of all individuals regardless of their gender, race, religion, political, ethnical, cultural or social background. Their profession demands the cultivation of empathy, compassion and understanding of the "other" as well as acceptance of a wide variety of human expressions. As cultures, traditions and languages are often subsumed into a melting pot, the rights and interests of socially diverse groups of people need to be protected. Social work education that encourages critical self-reflection in order to avoid bias goes hand in hand with human rights education that emphasizes the rights and protection of minority groups. Social work education combined with human rights education imparts a robust base to those who provide assistance and refuge to the vulnerable. The crisis on the US-Mexican border, the protests by freedom fighters in Hong Kong, the Syrian refugee crisis and the war in Yemen are current examples of human rights challenges.

Even if social workers do not come to contact with minority groups, international law and human rights education promote social consciousness and enable social workers to view social problems within a larger human rights context [24]. Armed with these tools, social workers have the ability to examine individual cases and social issues from a broad legal, social, political and global perspective.

\section{Conclusion}

Social work education aims to prepare students to become professional social workers with the ability to deal with problems of the hour. Social work practice interfaces with the legal world in many ways: when social workers execute power granted by the law, make decisions that affect the rights and interests of clients, or advocate for social policy change, to state a few examples. In our opinion, legal education should be an inseparable part of every B.A. program for it imparts to students basic knowledge about: laws pertaining to social work practice; key legal principles and concepts; human and civil rights; and the structure of the legal system.

Social workers are clearly not supposed to be lawyers, but we believe that they can greatly benefit from legal education in their work and that legal education enhances the professionalism of the profession. Since social workers engage with diverse groups of people, an interdisciplinary perspective will enrich their viewpoint and perceptions of people, situations and social interactions. Questions regarding how to approach a case legally and professionally, considerations that need to be weighed in the decision making process, identifying which aspects of a case require attention and whether a specific law should be applied are all better addressed when a social worker feels he/she has the ability to respond to these questions appropriately.

While the primary goal of legal education is to inform students about the legal aspects of their work, the long-term goal is to equip students with basic guidelines and tools needed to navigate the legal system. In their future work, students will encounter complex cases involving clients with diverse needs and a broad range of circumstances. Legal education imparts to students the tools needed to explore legal solutions to a case either independently or with the assistance of a legal professional with whom they can communicate effectively.

Our experience in providing legal education to social work students has been a positive one. Although the relationship between the two disciplines may not seem natural at first compared, for example, to clinical and psychotherapeutic work, students find legal courses interesting, practical and relevant to the profession. The courses also enhance their understanding of social problems covered in other courses such as domestic violence, community mental health and community work. Students report they have a positive experience and feel more empowered following the knowledge and information they acquire in class.

There is evidence that interdisciplinary training of social workers in law impacts on their job performance: when legal knowledge was applied to practical work, social workers felt better prepared for their jobs including working with legal professionals [17]. Moreover, a recent study found that human rights education is effective in raising awareness about human rights in regard to the gender perceptions of social work students [28].

Beyond informing students of specific legal principles and laws, the substantial goal of legal education, in our view, is to teach students how to bridge the gap between theory and practice. While students may learn about a specific law in class, in most cases, the law provides only general guidance and abstract concepts which need to be filled in later with relevant content. In our program, we teach students how to apply the abstract concepts of a law to specific cases and we attempt to build the set of skills needed for implementation of the law. For example, we discuss the meaning and implementation of professional discretion from legal and 
social work standpoints. We analyze the integrative work that needs to be made in order to combine professional social work knowledge with legal knowledge. We demonstrate, through case studies, discussion of news reports and role playing, the practical process of making judgments, arriving at conclusions, and applying the authority to intervene in other people's lives. This interdisciplinary context gives students the opportunity to examine cases from a more comprehensive perspective and develop the skills needed to engage in interdisciplinary problem-solving.

Human rights and civil rights education is of immense importance to preparing social work students for the challenges of the 21 st century, [20]. The rapid social changes that are occurring today demand robust, well-educated social workers who are able to stand in the frontline and protect the human dignity and rights of vulnerable people from various backgrounds, push against forces which seek to limit the legal rights of these people, and fight forcefully to maintain the values of the profession. Working with war and armed-conflict affected families and growing numbers of war-affected refugees resettling in the West is likely to take up a larger part of social work practice and social workers will need to cope with the challenges involved [29].

Another future challenge is the socio-economic consequences of artificial intelligence and robot technology which is prospected to result in massive unemployment and radical changes in the lives of individuals [30].

Some claim that the social contract, we have been used to, between government and citizens in democratic societies will detrimentally change. Even with employment retraining policies, the expectation is that large swathes of people will become unemployed, with no income and time to spare leading to an increase in crime, violence, poverty and hunger. Another big challenge is that of climate changes which is estimated to result, among other tragic consequences, in massive migrations of populations fleeing from affected areas. Escalating refugee crises in different parts of the world, the increase in hate crimes against minorities following massive migrations, unemployment and the rise of far right movements around the world [31] are also expected to exacerbate the situation.

A comprehensive legal education and realignment of social work with legal education is necessary in order to protect the human dignity and rights of all individuals. It is important for social workers to overcome their own bias towards people who are different in appearance, race, gender, belief system, religion, culture, language, ethnic background, and for them to educate their communities about the importance of accepting the "other." True human rights education requires critical self-reflection in order to un-root bias in our own internal world. Human rights is a concept that is based on the premise of universal, shared humanity between all people. This means that we are all human beings with inalienable rights. Transforming this knowledge into deep personal conviction is necessary in order to act in a humanitarian manner and protect the rights of those in need. The gravity of social work practice, in the present and future, demands professional training that is commensurate with the goal of the profession and legal education is a vital part of this training.

\section{References}

[1] Slater LK and Finck KR. Social work practice and the law. Springer Publishing Company, 2011.

[2] Braye S, Preston-Shoot M and Johns R. Law in social work education: Reviewing the evidence on teaching, learning and assessment. Social Work Education, 2005, 24(5): 547-563. https://doi.org/10.1080/02615470500132830

[3] Karpel M. Social workers' attitudes towards the law Social workers' attitudes towards the law. Thesis, School of Social Work, Haifa University, 2007.

[4] Madden RG. Legal content in social work education: Preparing students for inter-professional practice Journal of Teaching in Social Work, 2000, 20(1-2): 3-17. https://doi.org/10.1300/J067v20n01_02

[5] Wood DJ and Gray B. Toward a comprehensive theory of collaboration. Journal of Applied Behavioral Science, 1991, 27(2): 139-167. https://doi.org/10.1177/0021886391272001

[6] Bellard EM. Navigating the shoals: Legal research, social policy, and Social Work students. Behavioral \& Social Sciences Librarian, 2007, 26(1): 25-37. https://doi.org/10.1300/J103v26n01_02

[7] Kopels S and Gustavsson NS. Infusing legal issues into the social work curriculum. Journal of Social Work Education, 1996, 32(1): 115-125. https://doi.org/10.1080/10437797.1996.10672289

[8] Braye S, Preston-Shoot M and Johns R. Lost in translation? Teaching law to nonlawyers: Reviewing the evidence from social work. The Law Teacher, 2006, 40(2): 131-150. https://doi.org/10.1080/03069400.2006.9993203 
[9] Alon S. Social workers' intentions to employ legal or treatment interventions in cases of elder abuse. Dissertation, School of Social Work, Haifa University, 2004.

[10] Brayne H, Carr H and Goosey D. Law for social workers. Oxford University Press, USA, 2015.

[11] Barak A. On Society, Law, and Judging. Tulsa Law Review, 2011, 47: 297.

[12] Aiken J and Wizner S. Law as social work. Wash. UJL \& Pol'y, 2003, 11: 63.

[13] Gambrill E. Social work: An authority-based profession. Research on Social Work Practice, 2001, 11(2): 166-175 https://doi.org/10.1177/104973150101100203

[14] Goldshmidth S and Giron Y. Defining the status of Israeli social workers in the law. The Association for the Advancement of Social Work in Israel, 2018.

[15] Chambers JA. Child protection, youth justice and the legal process: Challenges for the children's court. Australian Social Work, 2019, 72(4): 389-391. https://doi.org/10.1080/0312407X.2018.1540646

[16] Budd KS, Clark JR and Connell M. Evaluation of parenting capacity in child protection. Oxford University Press, 2011. https://doi.org/10.1093/med:psych/9780195333602.001.0001

[17] Strand VC. Interdisciplinary training for effective implementation of services in response to a social policy change. Journal of Human Behavior in the Social Environment, 2006, 13(4): 37-53. https://doi.org/10.1300/J137v13n04_03

[18] Rumping S, Boendermaker L and de Ruyter DJ. Stimulating interdisciplinary collaboration among youth social workers: A scoping review. Health \& Social Care in the Community, 2019, 27(2): 293-305. https://doi.org/10.1111/hsc.12589

[19] Browne T. Social Work Roles and Healthcare Settings. Handbook of health social work, 2019: 21-37. https://doi.org/10.1002/9781119420743.ch2

[20] Martnez Herrero MI and Charnley H. Human rights and social justice in social work education: A critical realist comparative study of England and Spain. European Journal of Social Work, 2019, 22(2): 225-237. https://doi.org/10.1080/13691457.2018.1540407

[21] Logan J, Kershaw S, Karban K, et al. Confronting prejudice: Lesbian and gay issues in social work education. Routledge, 2017. https://doi.org/10.4324/9781315259642

[22] Kozakiewicz J. Social work and law: A model approach to interdisciplinary education, practice, and communitybased advocacy. Family Court Review, 2008, 46(4): 598-608. https://doi.org/10.1111/j.1744-1617.2008.00226.x

[23] Healy LM. Exploring the history of social work as a human rights profession. International Social Work, 2008, 51(6): 735-748. https://doi.org/10.1177/0020872808095247

[24] Mapp S, McPherson J, Androff D, et al. Social work is a human rights profession. Social Work, 2019, 64(3): 259-269. https://doi.org/10.1093/sw/swz023

[25] Fernando Chang-Muy JD and Congress EP. (Eds.). Social work with immigrants and refugees: Legal issues, clinical skills, and advocacy. Springer Publishing Company, 2015. https://doi.org/10.1891/9780826126696

[26] Lal R. Social and economic rights of refugees under international legal framework: An appraisal. Indian Journal of International Law, 2019: 1-22.

[27] Okech D, Choi YJ, Elkins J, et al. Seventeen years of human trafficking research in social work: A review of the literature. Journal of Evidence-Informed Social Work, 2018, 15(2): 103-122. https://doi.org/10.1080/23761407.2017.1415177

[28] Altnova HH, Duyan V and Megahead HA. The impact of the human rights education program for women on gender perceptions of social work students. Research on Social Work Practice, 2019, 29(1): $113-121$. https://doi.org/10.1177/1049731516679889

[29] Denov M and C Shevell M. Social work practice with war-affected children and families: The importance of family, culture, arts, and participatory approaches. Journal of Family Social Work, 2019, 22(1): 1-16. https://doi.org/10.1080/10522158.2019.1546809

[30] Makridakis S. The forthcoming Artificial Intelligence (AI) revolution: Its impact on society and firms. Futures, 2017, 90: 46-60. https://doi.org/10.1016/j.futures.2017.03.006

[31] Zavirek D and Rajgelj B. Anti-refugee sentiment without refugees: Human rights violations and social work in post-socialist countries of Southeastern Europe in their social contexts. Journal of Human Rights \& Social Work, 2019, 4(1): 5-16. https://doi.org/10.1007/s41134-018-0083-2 